\title{
Composition of bacteria harvested from the liquid and solid fractions of the rumen of sheep as influenced by feed intake
}

\author{
C. A. Rodríguez ${ }^{1}$, J. González ${ }^{1}$, M. R. Alvir ${ }^{1}$, J. L. Repetto ${ }^{1} \dagger$, C. Centeno ${ }^{2}$ and F. Lamrani ${ }^{1} \ddagger$ \\ ${ }^{1}$ Departamento de Producción Animal, Universidad Politécnica de Madrid, 28040 Madrid, Spain \\ ${ }^{2}$ Consejo Superior de Investigaciones Científicas, Instituto de Nutrición y Bromatología, 28040 Madrid, Spain
}

(Received 1 April 1998 - Revised 4 January 2000 - Accepted 18 January 2000)

\begin{abstract}
A study was conducted to determine the effect of the feed intake on the chemical composition of bacteria associated with the solid (solid-associated bacteria; SAB) and liquid (liquid-associated bacteria; $\mathrm{LAB}$ ) fractions of rumen digesta, the digestive passage kinetics and their relationships. Whole rumen contents were sampled after a period of continuous infusion of ${ }^{15} \mathrm{NH}_{3}$ from four ruminally-cannulated wethers provided successively with a hay-concentrate $\operatorname{diet}(2: 1 \mathrm{w} / \mathrm{w}$ on a $\mathrm{DM}$ basis) at two rates of feed intake: 40 and $80 \mathrm{~g} \mathrm{DM} / \mathrm{kg}$ body weight ${ }^{0.75}$. SAB had a higher content of organic matter and total lipids $(P<0.001)$ and a similar $\mathrm{N}$ content as compared with LAB. The concentration of purines and ${ }^{15} \mathrm{~N}$ was lower $(P=0.011$ and $P<0.001$ respectively) in $\mathrm{SAB}$ than $\mathrm{LAB}$, whereas the opposite was observed for the concentration of amino acids $(\mathrm{mg} / \mathrm{g}$ $\mathrm{DM} ; P=0.031)$. An increase in feed intake produced an increase in the $\mathrm{N}(P=0.034)$ and purine $(P=0.066)$ concentrations in bacteria and a decrease $(P=0.033)$ in their amino acid concentrations. Significant increases of rumen outflow rates of liquid and particles were also observed with increased feed intake. Rates of rumen outflow showed positive and negative linear relationships $(P<0.001)$ with the purine $: \mathrm{N}$ ratio and the proportion of amino acid on total $\mathrm{N}$ of bacteria respectively. SAB contained significantly higher proportions of leucine, isoleucine, lysine and phenylalanine and lower proportions of alanine, methionine and valine than LAB. The increase in feed intake also induced significant changes in the amino acid profile of bacteria, increasing arginine and methionine and decreasing alanine and glycine proportions. Results show that the outflow rate of rumen contents is a major factor in determining the proportion of nucleic acids and protein in rumen bacteria and explains some of the differences observed between LAB and SAB.
\end{abstract}

\section{Rumen bacteria: Chemical composition: Feed intake}

Microbial synthesis in the rumen and the microbial contribution to the nutrient flow to the duodenum have been calculated using internal or external marker ratios, which are generally determined on bacteria harvested from the liquid fraction of the rumen digesta (liquid-associated bacteria; LAB). However, bacteria associated with the solid fraction of rumen digesta (solid-associated bacteria; $\mathrm{SAB}$ ) are predominant in rumen contents and LAB represent only a small fraction of the total bacterial population (Legay-Carmier \& Bauchart, 1989). Moreover, it has been demonstrated that the chemical composition (Merry \& McAllan, 1983; Bauchart et al. 1986; Legay-Carmier \& Bauchart, 1989) and the metabolic functions (Latham, 1980; Williams \& Strachan, 1984) of both bacterial populations are different. Some of these differences are related to compounds used as microbial markers, such as RNA or purines (Merry \& McAllan, 1983; Bates et al. 1985; LegayCarmier \& Bauchart, 1989; Cecava et al. 1990), or the capture of ${ }^{15} \mathrm{~N}$ (Olubobokun \& Craig, 1990; Beckers et al. 1995). Therefore, the accuracy of estimates of rumen microbial synthesis or the microbial and dietary nutrient flow to the duodenum can be affected if LAB only are harvested. Moreover, there is evidence both in vitro and in vivo that changes in growth media and in growth rate can alter the composition of bacteria (Hespell \& Bryant, 1979; Bates et al. 1985; Craig et al. 1987b). This variability suggests the need for a more accurate assessment of the composition of both groups of micro-organisms.

In vivo studies on the influence of feeding conditions on the composition of rumen bacteria have mainly been

\footnotetext{
Abbreviations: AA, amino acids; $\mathrm{k}_{\mathrm{L}}$, rumen liquid dilution rate; $\mathrm{k}_{1}$, rumen particle outflow rate; $\mathrm{k}_{2}$, secondary rate constant; $\mathrm{LAB}$, liquid-associated bacteria; $\mathrm{SAB}$, solid-associated bacteria; T, transit time.

* Corresponding author: Dr C. A. Rodríguez, fax +349154997 63, email crodriguez@pan.etsia.upm.es

$\dagger$ Present address: Departamento de Nutrición Animal, Universidad de la Republica Oriental del Uruguay, 11600 Montevideo, Uruguay.

$\$$ Present address: Institut Technique D’elevage Bovin, Ovin et Caprin, Boite Postale 3, Baba Ali Bertouta, Algeria.
} 
focused on determining postprandial variations (Bates et al. 1985; Craig et al. 1987a) and the effects of diet composition, such as the forage : concentrate ratio (Martin et al. 1994) or the addition of unprotected fats (Legay-Carmier \& Bauchart, 1989). However, information on the possible effects of feed intake is very limited, in spite of its important influence on microbial growth rate through variation in the rate of rumen outflow. The present experiment was designed to examine the possible effects of the feed intake on the chemical composition of both types of bacteria.

\section{Materials and methods}

\section{Animals and feeding}

Four adult wethers (average body weight $62.2 \mathrm{~kg}$ ) equipped with detachable rumen fistulas (inner diameter $8 \mathrm{~cm}$ ) were fed a diet composed of chopped vetch-oat hay-concentrate ( $2: 1, \mathrm{w} / \mathrm{w}$ on a DM basis). The concentrate contained $(\mathrm{g} /$ $\mathrm{kg}$ ): corn grain 607, dehydrated beet pulp 300, soyabean meal 45 , fish meal 20 , bentonite 15 , minerals and vitamins 13. The diet was offered as six meals per d, at 4 hourly intervals, at two rates of DM intake: 40 (low) and 80 (high) $\mathrm{g} \mathrm{DM} / \mathrm{kg}$ body weight ${ }^{0.75}$, in successive experimental periods. Both rates of feed intake represent $1 \cdot 1$ and $2 \cdot 2$ times the maintenance requirements for energy and 1.6 and 3.2 times $\mathrm{N}$ requirements respectively. The chemical composition of the feeds is given in Table 1 .

\section{Experimental procedures}

After a $14 \mathrm{~d}$ period of adaptation to the diet, the rates of rumen outflow of hay and concentrate were determined by supplying a pulse dose of labelled feeds $(50 \mathrm{~g}$ concentrate and $60 \mathrm{~g}$ hay) in the stall of each animal immediately before the first morning meal (09.00 hours). The feeds had previously been washed with a commercial detergent in an automatic washing machine to eliminate the soluble components and labelled with $\mathrm{Yb}$ (concentrate) and Eu (hay) according to the recommendations of Ellis \& Beever (1984). Labelling was done by immersion for $24 \mathrm{~h}$ in a solution of $\mathrm{YbCl}_{3}$ or $\mathrm{EuCl}_{3}(20 \mathrm{mg} \mathrm{Yb}$ or $\mathrm{Eu} / \mathrm{g}$ feed $)$ and citric acid $\left(0.7 \mathrm{~mol} / \mathrm{mol} \mathrm{YbCl}_{3}\right.$ or $\left.\mathrm{EuCl}_{3}\right)$ at $\mathrm{pH} 2 \cdot 2$. The citric acid solution at a low $\mathrm{pH}$ was employed to avoid fixation of the marker on binding sites with low affinity. After labelling, the feed residues were carefully washed with water and dried at $65^{\circ} \mathrm{C}$ to approximately the original DM content. A

Table 1. Chemical composition ( $\mathrm{g} / \mathrm{kg} \mathrm{DM})$ of the hay and concentrate in the diet

\begin{tabular}{lcc}
\hline Item & Hay $^{*}$ & Concentrate† \\
\hline Ash & 150 & 62 \\
Crude protein & 144 & 128 \\
Ether extract & 31.9 & 28.3 \\
Neutral-detergent fibre & 451 & 245 \\
Acid-detergent fibre & 282 & 118 \\
Acid-detergent lignin & 44.7 & 17.8 \\
\hline
\end{tabular}

${ }^{*}$ Hay $(\mathrm{g} / \mathrm{kg})$ : Vicia sativa 550 , Avena sativa 450.

† Concentrate $(\mathrm{g} / \mathrm{kg})$ : corn grain 607 , dehydrated beet pulp 300 , soyabean meal 45, fish meal 20 , bentonite 15 , minerals and vitamins 13. total of twenty-three samples of faeces from each animal were obtained from the rectum, the first before supplying the marker, and the rest between 9 and $144 \mathrm{~h}$ afterwards. These samples were dried, milled and analysed for $\mathrm{Yb}$ and $\mathrm{Eu}$. The pattern of rare earth concentrations in faeces with time was fitted using the model proposed by Dhanoa et al. (1985). This model includes two fractional rate constants: $\mathrm{k}_{1}$, which represents the outflow of particles from the rumen; and $\mathrm{k}_{2}$ whose biological meaning is not well established; and a transit time $(\mathrm{T})$ in the remaining compartments of the digestive tract.

Throughout the rest of the experiment, the rumen microorganisms were labelled with a $50 \%$ enriched $\left({ }^{15} \mathrm{NH}_{4}\right)_{2} \mathrm{SO}_{4}$ solution (ICON Service Inc., NJ, USA). This solution (200 mg N/l) was continually infused into the rumen at a rate of $400 \mathrm{ml} / \mathrm{d}$, for at least $30 \mathrm{~d}$ before rumen sampling.

At the end of each experimental period the rumen was manually emptied just before the first morning meal. The rumen contents were homogenized and samples of SAB and LAB were isolated from a $1.2 \mathrm{~kg}$ sample (fresh matter) of rumen digesta. The rumen samples were squeezed through a double layer of nylon cloth (pore size $46 \mu \mathrm{m}$ ). Retained particles (enclosed in the cloth) were subjected to three successive cycles of washing and shaking in a total volume of $700 \mathrm{ml}$ saline solution $(9 \mathrm{~g} \mathrm{NaCl} / \mathrm{l})$ at $4-5^{\circ} \mathrm{C}$ to remove fluid-associated microbes. The rumen liquid and saline wash fractions were centrifuged at $500 \mathrm{~g}$ for $10 \mathrm{~min}$ to remove feed particles and protozoa. The supernatant obtained was centrifuged at $25400 \mathrm{~g}$ for $15 \mathrm{~min}$ to obtain LAB samples. The pellet collected from the $500 \mathrm{~g}$ centrifugation was added to the solid digesta sample prior to detachment of adherent bacteria using the method described by Merry \& McAllan (1983). For this purpose, the solid digesta was re-suspended in saline solution $(2 \mathrm{l} / \mathrm{kg})$ and homogenized. The homogenate was pummelled for $6 \mathrm{~min}$ in a stomacher and squeezed as described for the rumen content. SAB were isolated from this liquid by the centrifugation procedure described earlier. SAB and LAB isolates were lyophilized and analysed for organic matter, total lipids, $\mathrm{N},{ }^{15} \mathrm{~N}$ abundance $\left({ }^{15} \mathrm{~N}: \mathrm{N}\right)$, purines and amino acids (AA).

To establish the rumen liquid dilution rate $\left(\mathrm{k}_{\mathrm{L}}\right)$, a LiCrEDTA salt was prepared as described by Uden et al. (1980) and continuously infused (298.54 $\mu \mathrm{g} \mathrm{Cr} / \mathrm{ml}$ added to the $\left({ }^{15} \mathrm{NH}_{4}\right)_{2} \mathrm{SO}_{4}$ solution) over the $3 \mathrm{~d}$ before the rumen sampling. The $\mathrm{k}_{\mathrm{L}}$ values were determined as total rumen $\mathrm{Cr}$ content : Cr daily dose ratio.

\section{Analytical procedures}

The analytical procedures used to determine the DM, organic matter and $\mathrm{N}$ content of $\mathrm{SAB}$ and $\mathrm{LAB}$ fractions were those described by the Association of Official Analytical Chemists (1984). The chemical composition of the hay and concentrate used in the diet were determined by the same methods except for the fibre fractions (Robertson \& Van Soest, 1981). Lipids in bacterial samples were extracted with a chloroform-methanol mixture $(2: 1, \mathrm{v} / \mathrm{v})$ as described by Folch et al. (1957). $\mathrm{N}$ isotopic proportions in SAB and LAB samples were analysed by isotope-ratio MS (VG Prism II; VS Isotech, Ches., UK) which was linked in series to a Dumas-style N analyser EA 1108 (Carlo Erba Instruments, 
Milan, Italy). Purines in bacteria samples were determined by HPLC as described by Balcells et al. (1992). AA were also determined by HPLC after derivation following the technique of Jones et al. (1981), but using a fluorescence detector only. Proline, cystine and tryptophan were not determined due to technical limitations.

The samples of faeces collected for transit studies were ashed $\left(550^{\circ} \mathrm{C}\right)$ and then digested by boiling in a solution of $1.5 \mathrm{M}-\mathrm{HNO}_{3}$ and $\mathrm{KCl}(3.81 \mathrm{~g} / \mathrm{l})$. The solutions obtained were analysed for $\mathrm{Yb}$ and Eu by atomic absorption and emission spectrometry respectively (Smith-Hieftje 22; Thermo Jarrell Ash Corp., Franklin, MA, USA). The Cr analyses were done by atomic absorption spectrometry. Sample preparation again involved ashing $\left(550^{\circ} \mathrm{C}\right)$ and digestion by boiling in a solution of $1.5 \mathrm{M}-\mathrm{HNO}_{3}$.

\section{Statistical analysis}

All the statistical analyses were performed with the Statistical Analysis System for Windows software, version 6.12 (1990; SAS Institute Inc., Cary, NC, USA). The transit kinetics of hay and concentrate were fitted by non-linear regression using the method DUD (does not use derivatives) of the NLIN procedure (SAS Institute Inc.). The experimental design was a complete block, simple for the dilution rate study, or with a split-plot arrangement of treatments for the remaining variables studied. As the animals were adult with restricted feeding and maintained in a controlled environment, the period effect was assumed to be negligible. For the analysis of the transit kinetics variables of particles, the feed intake (low $v$. high) was the whole-plot treatment and was tested using animal $\times$ feed intake interaction as the error term. Type of feed (hay $v$. concentrate) and the interaction with feed intake were the sub-plot treatments. In the same manner, for the analysis of the bacteria chemical composition, feed intake (low $v$. high) was also the whole-plot treatment, tested using animal $\times$ feed intake interaction as the error term, and type of bacteria $(\mathrm{SAB} v . \mathrm{LAB})$ and interaction with feed intake as the subplot treatments.

\section{Results}

\section{Effect of feed intake on transit kinetics}

Mean dilution rate values in the rumen $\left(\mathrm{k}_{\mathrm{L}}\right)$ increased from 6.64 to $10.5 \% / \mathrm{h}(P=0.005$, SE 0.369$)$ with the increase in feed intake. The mean values for the transit kinetics variables for the hay and concentrate of the diet are presented in Table 2. Mean rumen outflow rates $\left(\mathrm{k}_{1}\right)$ also increased $(P=$ $0.007)$ with feed intake, having higher values for the concentrate, but not significantly $(P=0 \cdot 105)$. These increases in the rumen outflow are associated with an increase in the rumen contents (from 25 to $38.5 \mathrm{~g} \mathrm{DM} / \mathrm{kg}$ body weight ${ }^{0.75}$, $P=0.028$, SE 2.39). On the other hand, the fractional rate $\mathrm{k}_{2}$ showed higher values for concentrate $v$. hay $(P=0.002)$, so was not affected by the rate of feed intake.

Estimates of retention time in other compartments (T) showed a decrease $(P=0 \cdot 006)$ when feed intake increased. There was also a significant effect $(P<0.001)$ for the type of feed corresponding to lower times for the concentrate.

As a consequence of these variations, the mean retention time in the whole digestive tract was lower for the higher feed intake $(P=0.002)$ and for concentrate $v$. hay $(P<$ $0.001)$. The interaction of the feed intake with the feed type was not significant for any of the variables studied.

\section{Chemical composition of solid-associated bacteria and liquid-associated bacteria}

The mean values for the chemical composition of LAB and $\mathrm{SAB}$ isolates at both rates of feed intake are presented in Table 3. Large differences in composition were observed between $\mathrm{LAB}$ and $\mathrm{SAB}$ and between rates of feed intake. The SAB showed significantly higher values for organic matter and total lipids than LAB $(P<0 \cdot 001)$, but no significant effects were detected in both variables for feed intake or the interactions. With an increase in feed intake the $\mathrm{N}$ concentration of bacteria showed a moderate increase $(P=$ 0.034). However, no differences were found between the type of bacteria or the interaction of the feed intake with the type of bacteria.

Table 2. Effect of feed intake and type of feed component on the transit of particles in the digestive tract

(Mean values for four sheep with pooled standard error of the mean)

\begin{tabular}{lccccc}
\hline & & & \multicolumn{2}{c}{ Transit variables } & \\
\cline { 3 - 4 } Feed component & Feed intake* & $\mathrm{k}_{1}(\% / \mathrm{h})$ & $\mathrm{k}_{2}(\% / \mathrm{h})$ & $\mathrm{T}(\mathrm{h})$ & MRT $(\mathrm{h})$ \\
\hline Hay & Low & 3.29 & 14.7 & 26.6 & 64.0 \\
Concentrate & High & 6.80 & 17.0 & 18.0 & 38.8 \\
& Low & 3.61 & 21.5 & 20.0 & 54.3 \\
Main effects & High & 7.30 & 27.4 & 13.0 & 30.8 \\
$\begin{array}{l}\text { Feed intake } \\
\quad \text { Pooled SEM }\end{array}$ & & & & & \\
$\quad P$ & 0.39 & 1.76 & 0.85 & 1.56 \\
Feed & & 0.007 & 0.148 & 0.006 & 0.002 \\
$\quad$ Pooled SEM & & 0.15 & 0.82 & 0.46 & 0.60 \\
$\quad P$ & 0.105 & $<0.001$ & $<0.001$ & $<0.001$ \\
\hline
\end{tabular}

$\mathrm{k}_{1}$, rumen particulate outflow rate; $\mathrm{k}_{2}$, secondary rate constant; $\mathrm{T}$, transit time; MRT, mean retention time $\left(1 / \mathrm{k}_{1}+\right.$ $\left.1 / k_{2}+T\right)$.

* Low, $40 \mathrm{~g} \mathrm{DM} /$ body weight $^{0.75}$; High, $80 \mathrm{~g} \mathrm{DM} /$ body weight ${ }^{0.75}$. For details of diet see Table 1 and p. 370. 
Table 3. Chemical composition of bacteria samples isolated from liquid and solid fractions of rumen samples as affected by feed intake (Mean values for four sheep with pooled standard error of the mean)

\begin{tabular}{|c|c|c|c|c|c|c|c|c|}
\hline \multirow[b]{3}{*}{ Item } & \multicolumn{4}{|c|}{ Feed intake* } & \multicolumn{4}{|c|}{ Significance of effects $†$} \\
\hline & \multicolumn{2}{|c|}{ Low } & \multicolumn{2}{|c|}{ High } & \multicolumn{2}{|c|}{ Low v. High } & \multicolumn{2}{|c|}{ SAB v. LAB } \\
\hline & SAB & LAB & SAB & $\mathrm{LAB}$ & Pooled SEM & $P$ & Pooled SEM & $P$ \\
\hline Organic matter (mg/g DM) & 793 & 722 & 811 & 740 & $5 \cdot 8$ & 0.114 & $6 \cdot 7$ & $<0.001$ \\
\hline Total lipids (mg/g DM) & 155 & 112 & 154 & 102 & 3.9 & 0.44 & $5 \cdot 3$ & $<0.001$ \\
\hline Nitrogen (mg/g DM) & $70 \cdot 4$ & $69 \cdot 3$ & $73 \cdot 2$ & $71 \cdot 3$ & 0.5 & 0.034 & 0.7 & 0.207 \\
\hline${ }^{15} \mathrm{~N}: \mathrm{N}($ atom \%) & 0.521 & 0.563 & 0.452 & 0.471 & 0.010 & 0.012 & 0.002 & $<0.001$ \\
\hline Purines ( $\mu \mathrm{mol} / \mathrm{g}$ DM) & $42 \cdot 4$ & $59 \cdot 5$ & $56 \cdot 6$ & 75.9 & 3.83 & 0.066 & 3.56 & 0.011 \\
\hline Purines/N $(\mu \mathrm{mol} / \mathrm{g} \mathrm{N})$ & 602 & 860 & 772 & 1065 & $67 \cdot 1$ & 0.090 & $47 \cdot 4$ & 0.006 \\
\hline Total amino acids (mg/g DM) & 360 & 338 & 318 & 283 & $9 \cdot 10$ & 0.033 & $7 \cdot 16$ & 0.031 \\
\hline Amino acid-N/total N ( \%)§ & 66.5 & 63.5 & 56.5 & $51 \cdot 4$ & 1.67 & 0.018 & 0.87 & 0.016 \\
\hline
\end{tabular}

$\mathrm{SAB}$, solid-associated bacteria; $\mathrm{LAB}$, liquid-associated bacteria.

${ }^{*}$ Low, $40 \mathrm{~g} \mathrm{DM} /$ body weight $^{0.75}$; High, $80 \mathrm{~g} \mathrm{DM} /$ body weight $^{0.75}$. For details of diet see Table 1 and p. 370.

† Effect of the interaction $(P=0.005)$ for ${ }^{15} \mathrm{~N}: \mathrm{N}$

$\ddagger$ Total analysed amino acids.

$\S$ Not including amide $\mathrm{N}$.

The ${ }^{15} \mathrm{~N}$ abundance was lower in $\mathrm{SAB}(P<0.001)$ than in $\mathrm{LAB}$, and decreased significantly $(P=0.012)$ with the increase in feed intake. The interaction effect was also significant $(P=0 \cdot 005)$. At the same time, differences were also observed among animals $(P<0.001)$ for the ${ }^{15} \mathrm{~N}: \mathrm{N}$ ratio, with mean values ranging from 0.4863 to 0.5294 atom $\%$.

Results for the concentration of purines $(\mu \mathrm{mol} / \mathrm{g} \mathrm{DM})$ show significant differences between types of bacteria $(P=$ $0 \cdot 011)$, with lower mean values for SAB than for LAB ( 49.5 v. 67.7). The increase in feed intake produced an important increase in purine concentration (average value $30 \%, P=$ $0 \cdot 066)$. The purine: $\mathrm{N}$ ratio shows a similar effect for the type of bacteria $(P=0.006)$ and also an important increase (mean value $25.7 \%)$ with the increase in feed intake $(P=0.09)$. No effects related to the type of bacteria or the feed intake were observed for individual purine proportions. Thus, mean proportions for adenine and guanine were 0.426 and 0.574 for $\mathrm{SAB}$ and 0.413 and 0.587 for $\mathrm{LAB}$ respectively.

Lower values were found for the total AA concentration $(P=0.031)$ and for AA-N : N $(P=0.016)$ in LAB. In addition, the increase in feed intake produced a decrease in the total AA expressed in terms of DM or N $(P=0.033$ and $P=$ 0.018 respectively).

The composition of $\mathrm{AA}$ in $\mathrm{SAB}$ and $\mathrm{LAB}$ at both feed intakes is presented in Table 4 . The SAB isolates generally contained more leucine $(P=0.035)$, isoleucine $(P=0.049)$, lysine $(P=0.01)$ and phenylalanine $(P=0.006)$ and less

Table 4. Amino acids composition ( $\%$ of total analysed amino acids) of bacteria isolated from solid and liquid fractions of rumen samples in response to feed intake

(Mean values for four sheep with pooled standard error of the mean)

\begin{tabular}{|c|c|c|c|c|c|c|c|c|}
\hline \multirow[b]{3}{*}{ Amino acid } & \multicolumn{4}{|c|}{ Feed intake* } & \multicolumn{4}{|c|}{ Significance of effects $†$} \\
\hline & \multicolumn{2}{|c|}{ Low } & \multicolumn{2}{|c|}{ High } & \multicolumn{2}{|c|}{ Low v. High } & \multicolumn{2}{|c|}{ SAB v. LAB } \\
\hline & SAB & LAB & SAB & LAB & Pooled SEM & $P$ & Pooled SEM & $P$ \\
\hline Arginine & $4 \cdot 28$ & 4.52 & 4.58 & 4.62 & 0.04 & 0.035 & 0.06 & 0.163 \\
\hline Histidine & $1 \cdot 32$ & $1 \cdot 31$ & 1.55 & 1.39 & 0.04 & 0.053 & 0.04 & 0.167 \\
\hline Isoleucine & 6.53 & $6 \cdot 02$ & $6 \cdot 18$ & $6 \cdot 20$ & 0.05 & 0.314 & 0.07 & 0.05 \\
\hline Leucine & 7.99 & 8.08 & 8.07 & $7 \cdot 42$ & 0.08 & 0.083 & 0.07 & 0.035 \\
\hline Lysine & 7.99 & 6.93 & $7 \cdot 60$ & $6 \cdot 68$ & 0.25 & 0.445 & 0.19 & 0.01 \\
\hline Methionine & $2 \cdot 20$ & $2 \cdot 27$ & $2 \cdot 23$ & $2 \cdot 78$ & 0.06 & 0.045 & 0.05 & 0.006 \\
\hline Phenylalanine & $5 \cdot 62$ & $5 \cdot 40$ & $5 \cdot 68$ & $5 \cdot 06$ & 0.08 & 0.302 & 0.07 & 0.006 \\
\hline Threonine & 5.85 & $5 \cdot 66$ & $6 \cdot 25$ & $5 \cdot 77$ & 0.19 & 0.427 & 0.17 & 0.23 \\
\hline Valine & $5 \cdot 70$ & $6 \cdot 21$ & $5 \cdot 47$ & 6.57 & 0.09 & 0.623 & 0.06 & $<0.001$ \\
\hline Essential amino acids & $46 \cdot 2$ & $45 \cdot 1$ & $46 \cdot 1$ & $45 \cdot 1$ & 0.42 & 0.958 & 0.30 & 0.056 \\
\hline Alanine & $6 \cdot 15$ & $7 \cdot 47$ & 5.98 & 6.64 & 0.05 & 0.005 & 0.09 & $<0.001$ \\
\hline Aspartic acid & $14 \cdot 3$ & 13.9 & $14 \cdot 2$ & $14 \cdot 8$ & 0.20 & 0.213 & 0.17 & 0.664 \\
\hline Glutamic acid & $16 \cdot 4$ & $16 \cdot 6$ & $16 \cdot 8$ & $17 \cdot 1$ & 0.20 & 0.189 & 0.16 & 0.408 \\
\hline Glycine & $5 \cdot 21$ & $5 \cdot 36$ & 4.90 & 4.80 & 0.05 & 0.007 & 0.10 & 0.876 \\
\hline Serine & $5 \cdot 20$ & $5 \cdot 06$ & $5 \cdot 08$ & $4 \cdot 79$ & $0 \cdot 10$ & 0.263 & 0.07 & 0.074 \\
\hline Tyrosine & $5 \cdot 30$ & $5 \cdot 24$ & $5 \cdot 32$ & $5 \cdot 36$ & 0.06 & 0.454 & 0.08 & 0.957 \\
\hline
\end{tabular}

$\mathrm{SAB}$, solid-associated bacteria; $\mathrm{LAB}$, liquid-associated bacteria

${ }^{*}$ Low, $40 \mathrm{~g} \mathrm{DM} /$ body weight ${ }^{0.75}$; High, $80 \mathrm{~g} \mathrm{DM} /$ body weight ${ }^{0.75}$. For details of diet see Table 1 and p. 370

$\dagger$ Effect of the interaction for alanine, leucine, isoleucine, methionine and valine: $P<0.05$. 
alanine $(P<0.001)$, valine $(P<0.001)$ and methionine $(P=$ $0.006)$ than LAB. The increase in feed intake produced a decrease in the proportions of alanine $(P=0.005)$ and glycine $(P=0.007)$, and an increase in those of arginine $(P=0.035)$ and methionine $(P=0.045)$. Interactions $(P<$ 0.05 ) were observed for alanine, leucine, isoleucine, methionine and valine.

\section{Effect of rumen outflow rates on purines and total amino acid concentrations of solid-associated bacteria and liquid-associated bacteria}

The concentration of purines in bacteria showed a linear relationship with the rumen outflow rates (Fig. 1(a)). A similar relationship was observed for the purine: $\mathrm{N}$ ratio (Fig. 1(b)). The outflow rates considered for LAB were those corresponding to the liquid rumen fraction $\left(\mathrm{k}_{\mathrm{L}} 6.64\right.$ and $10.5 \% / \mathrm{h}$ for low and high feed intakes respectively) and for $\mathrm{SAB}$ those corresponding to the particulate rumen phase ( $\mathrm{k}_{1} 3.40$ and $6.97 \% / \mathrm{h}$ for low and high intake levels respectively), calculated as the weighted average of hay and concentrate $\mathrm{k}_{1}$ values (Table 2) in relation to the proportion of these feeds in the diet $(2: 1)$.

The total AA concentration and the $A A-\mathrm{N}: \mathrm{N}$ ratio of $\mathrm{SAB}$ and $\mathrm{LAB}$ also show linear relationships with the rumen outflow rates (Fig. 2(a) and (b) respectively).

No other relationships with the rumen outflow rate were observed for the remaining variables studied.

\section{Discussion}

\section{Effect of feed intake over transit kinetics}

The allocation of rate constants to specific compartments in the digestive tract is not totally clear. There is a general agreement that the smallest rate constant $\left(\mathrm{k}_{1}\right)$ represents the rumen outflow, but the allocation of the fastest rate constant $\left(\mathrm{k}_{2}\right)$ is more uncertain. Grovum \& Williams (1973) and Dhanoa et al. (1985) suggested that $\mathrm{k}_{2}$ probably described caecum outflow while Ellis et al. (1979) proposed that this rate could be ascribed to an intrarumen compartment associated with mixing and comminution of particles. In addition, the possibility of a combined effect of both compartments has been indicated (Ellis et al. 1988). The differences observed between feeds for $\mathrm{k}_{2}$ agree with the latter observation because the behaviour of hay and concentrate particles in the caecum should be similar due to the high viscosity of the digesta (Dixon et al. 1982). On the other hand, important differences in the behaviour of hay and concentrate particles can be expected at rumen level.

The increase of the rumen turnover rate of liquid and particles (hay and concentrate) observed with the increase in feed intake agrees with the overall conclusions obtained from the works carried out on this subject (Poncet, 1991). This increase is associated with the higher rumen pressure (due to the increase in rumen content) and rumen motility (contractile and propulsive movements) that makes a higher evacuation through the reticulo-omasal orifice possible (Waghorn \& Reid, 1977). The increase in rumen outflow should accelerate the transit in the post-rumen compartments, which is in agreement with the reduction of $\mathrm{T}$ values
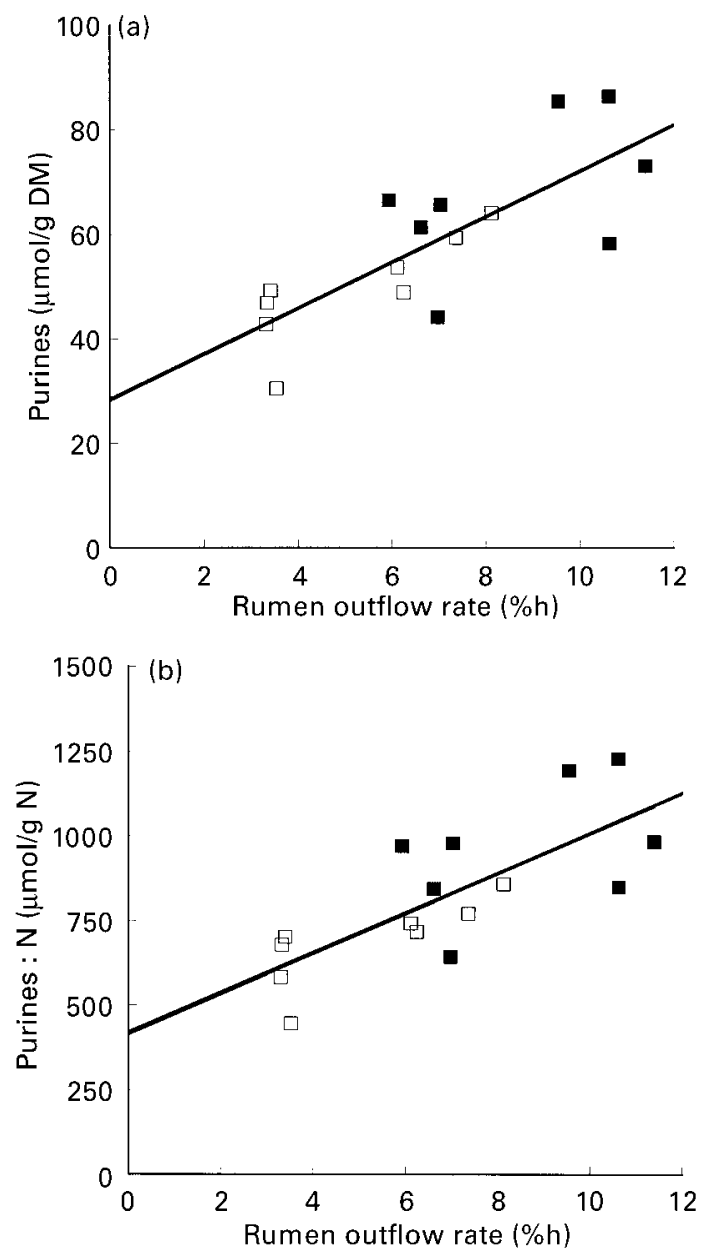

Fig. 1. Relationships between the rumen outflow rates $(k=$ rumen particle outflow rate $\left(\mathrm{k}_{1}\right)$ or rumen liquid dilution rate $\left.\left(\mathrm{k}_{\mathrm{L}}\right) ; \% / \mathrm{h}\right)$ and $(\mathrm{a})$ the purine concentration ( $\mu \mathrm{mol} / \mathrm{g} \mathrm{DM})$ or $(\mathrm{b})$ the purine: $\mathrm{N}$ ratio $(\mu \mathrm{mol} /$ $\mathrm{g} \mathrm{N}$ ) of $(\square)$, solid associated and ( $\square$ ), liquid associated bacteria. The experimental animals were four adult wethers (mean body weight $62.2 \mathrm{~kg}$ ) fed on a diet described in Table 1 at two rates of DM intake: 40 (low) and 80 (high) g DM/kg body weight ${ }^{0.75}$ in successive experimental periods. Regression equations were: purine concentration $=28.3+4.40 \times \mathrm{k}\left(\mathrm{RSD} 9.92, R^{2} 0.602, P<0.001, n 16\right) ;$ purine $: \mathrm{N}$ ratio $=414.7+59.5 \times \mathrm{k}\left(\operatorname{RSD} 143, R^{2} 0.571, P<0.001, n 16\right)$.

and also, considering the hypothesis of Ellis et al. (1988) mentioned earlier, with the apparent increase observed for $\mathrm{k}_{2}$ when intake increases.

\section{Chemical composition of rumen bacteria}

Chemically, SAB and LAB were clearly different, as observed in most previous reports. The higher organic matter concentration observed in SAB than LAB agrees with most studies carried out on this subject as previously indicated by Martin et al. 1994. This difference could be partially associated with the higher lipid concentration observed in SAB in this study (Table 3). The differences in lipid concentration between SAB and LAB could explain on average $67 \%$ of the differences observed for the organic matter concentration. A higher lipid concentration in $\mathrm{SAB}$ than LAB has also been observed by Merry \& McAllan 

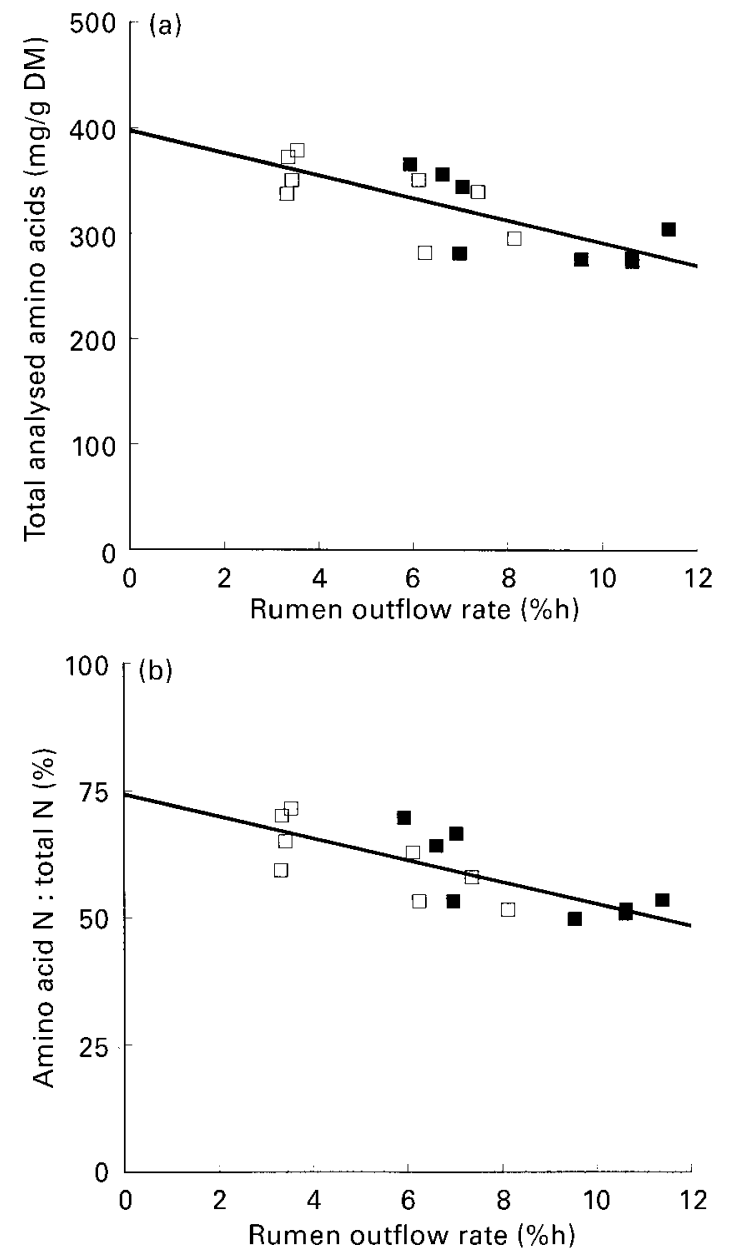

Fig. 2. Relationships between the rumen outflow rate $(k=$ rumen particle outflow rate $\left(\mathrm{k}_{1}\right)$ or rumen liquid dilution rate $\left.\left(\mathrm{k}_{\mathrm{L}}\right) ; \% / \mathrm{h}\right)$ and (a) the total analysed amino acid concentration (mg/g DM) or (b) the

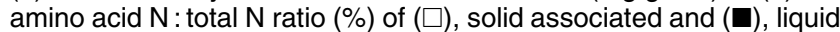
associated bacteria. The experimental animals were four adult wethers (mean body weight $62.2 \mathrm{~kg}$ ) fed on a diet described in Table 1 at two rates of DM intake: 40 (low) and 80 (high) $\mathrm{g} \mathrm{DM} / \mathrm{kg}$ body weight ${ }^{0.75}$ in successive experimental periods. Regression equations were: total analysed amino acids $=398-10.6 \times \mathrm{k}$ (RSD 26.9, $\left.R^{2} 0.544, P=0.001, n 16\right)$; amino acid $\mathrm{N}$ : total $\mathrm{N}$ ratio $=74.3-$ $2.15 \times \mathrm{k}\left(\right.$ RSD 5.28, $\left.R^{2} 0.56, P<0.001, n 16\right)$.

(1983) and Legay-Carmier \& Bauchart (1989). These authors explained this difference by a higher concentration in lipids or microbial lipid precursors (fatty acids, acetate) in the micro-environment of SAB, which can lead to increased lipid synthesis and/or adsorption (Harfoot, 1981) of dietary fatty acids onto bacterial cells. In addition, it is also possible that the higher lipid concentration in SAB could be related to a lower proportion of Gram-positive bacteria, as bacterial lipids are mainly associated with the bacterial cell wall, and lipid concentration in the cell wall is markedly lower in Gram-positive than in Gram-negative bacteria (Cummins, 1989).

The similar $\mathrm{N}$ concentration observed in $\mathrm{SAB}$ and $\mathrm{LAB}$ agrees with the results of Bauchart et al. (1986) and Craig et $a l$. (1987b) and also with those obtained by LegayCarmier \& Bauchart (1989) with a diet not supplemented with oil. On the other hand, some authors determined lower $\mathrm{N}$ concentrations in SAB than LAB (Merry \& McAllan, 1983; Komisarczuk et al. 1987; Legay-Carmier \& Bauchart, 1989, with an oil-supplemented diet), while others (Firkins et al. 1987; Benchaar et al. 1995) observed the opposite effect.

Results in this present study support general findings of a lower ${ }^{15} \mathrm{~N}: \mathrm{N}$ ratio in $\mathrm{SAB}$ than in $\mathrm{LAB}$ as systematically reported (Komisarczuk et al. 1987; Cecava et al. 1990; Olubobokun et al. 1990; Martin et al. 1994; Beckers et al. 1995). This difference indicates a lower utilization by SAB of the infused $\mathrm{NH}_{3}$ and therefore, of a preferential use of the nitrogenous compounds derived from the degradation of the feed particles that they colonize. To explain this effect, Komisarczuk et al. (1987) suggested a higher direct incorporation of amino acids and oligopeptides by SAB than LAB. Nevertheless, it is more likely that this effect is due to a lower ${ }^{15} \mathrm{~N}: \mathrm{N}$ ratio in $\mathrm{NH}_{3}$ in the micro-environment of $\mathrm{SAB}$, as consequence of diffusion difficulties inside of the microbial micro-colonies. This difficulty for the interchange of nutrients had been indicated by Pirt (1975). The reduction of ${ }^{15} \mathrm{~N}$ abundance observed for bacteria with the increase in feed intake should be associated mainly with a higher marker dilution in the rumen liquor, as the marker infusion dose was the same $\left(40 \mathrm{mg}{ }^{15} \mathrm{~N} / \mathrm{d}\right)$ in both assays.

The lower concentration of purines in SAB agrees with previous results (Merry \& McAllan, 1983; Legay-Carmier \& Bauchart, 1989; Benchaar et al. 1995). The different concentration between both bacterial populations, as well as the observed tendency to increase $(P=0.066)$ with increase in the feed intake are probably related to differences in bacterial growth rate associated with the variation of the turnover rates (Fig. 1(a)). Bates et al. (1985) demonstrated a close and direct relationship between RNA concentrations and growth rates of rumen bacteria in in vitro assays, which can be explained by the higher protein synthesizing machinery that is necessary for a higher growth rate.

Similarly, the negative relationship (Fig. 2(a)) found between the total AA concentrations of both populations of bacteria and the rumen outflow rates should be a consequence of the fact that bacterial growth rate determines the cellular physiological state (cell size and nucleic acids and protein contents). Thus, nutrition-imposed growth rate studies developed with Salmonella typhimurium (Schaechter et al. 1958) or Escherichia coli (Bremer \& Dennis, 1987) show that the bacterial cell mass, RNA and protein are exponential functions of the growth rate. Nevertheless, as RNA increases faster than cell mass, while protein increases somewhat more slowly than cell mass, a superior growth rate implies an important increase in the RNA concentration and a moderate decrease in the protein concentration of bacteria. This is in agreement with the higher slope of the regression line obtained for purines compared with that of total AA (Fig. 1(a) and 2(a) respectively).

The opposite trends of purine and total AA concentrations with the turnover rates partly explains the relatively constant concentration of $\mathrm{N}$ in both bacterial populations, because the higher concentration of purines in LAB samples are balanced by a lower AA concentration. These opposite relationships also agree with that found by Bates et al. 
(1985) between the RNA: protein ratio and the bacterial growth rate. Both relationships show that the rumen transit rate associated with each bacterial population is one of the main factors that influence their cellular composition of nitrogenous compounds.

Martin et al. (1996) compared the AA composition of $\mathrm{SAB}$ and $\mathrm{LAB}$ as a function of time after feeding and diet composition and observed many differences for individual AA, although for some of them (cystine, threonine, valine, serine and aspartic acid) this effect was only detected in one of two studies. The results of the present study support the results of Martin et al. (1996) for leucine, phenylalanine and alanine, but not for arginine, histidine, methionine and glycine. On the contrary, our results (Table 4) show significant differences for isoleucine and lysine, which were not observed by Martin et al. (1996).

Differences in AA composition between both bacterial populations may reflect the different species present in the liquid and solid fractions of the rumen digesta. Therefore, the higher alanine concentration in LAB may reflect a higher proportion of Gram-positive species in free-floating bacteria. D-Alanine and L-alanine are the main AA of the tetra-peptide that constitutes the peptidoglycan (murein) of bacterial cell walls, and murein forms a large proportion of the wall in Gram-positive organisms (50\% or more) whereas in Gram-negative organisms it usually forms less than $10 \%$ of the wall, and sometimes as little as $1 \%$ (Cummins, 1989). As diaminopimelic acid is another of the most abundant AA in this tetra-peptide, its concentration should also be higher in LAB than in SAB, and this effect is usually observed (Merry \& McAllan, 1983; Firkins et al. 1987; Legay-Carmier \& Bauchart, 1989; Martin et al. 1994).

The variations in AA composition of bacteria related to the feed intake could be the result of changes in species composition of rumen flora and also of variations in the physiological state of the cells associated with changes in growth and turnover rates, which can alter their cell wall : protoplasm ratio and, therefore, the proportions of some AA.

\section{Effects of marker and bacteria reference sample choice on the reliability of microbial estimations}

The LAB only represents a low proportion of the rumen bacterial population (Legay-Carmier \& Bauchart, 1989), so the use of ${ }^{15} \mathrm{~N}: \mathrm{N}$ or purine $: \mathrm{N}$ ratios established on samples of LAB result in underestimations of microbial protein flow and the efficiency of microbial protein synthesis as well as in studies of microbial colonization of feeds. The significance of this underestimation can be appreciated by the ratio of $\mathrm{N}$ : marker in $\mathrm{LAB}$ with $\mathrm{N}$ : marker in $\mathrm{SAB}$. Therefore, this results in higher errors when purines are employed $(0.70$ and 0.73 for low and high feed intakes respectively) than with the use of ${ }^{15} \mathrm{~N}(0.93$ and 0.96 for low and high feed intakes respectively).

In relation to the use of purines as microbial markers, the dependency of the purine: $\mathrm{N}$ ratio on the rumen outflow rates (Fig. 1(b)) shows that this ratio cannot be considered as a constant as it changes with the conditions for bacterial growth. This variability represents an important limitation for those cases where direct estimation of this ratio is not carried out, such as when microbial protein synthesis is estimated from the excreted urinary purine derivatives.

Estimations of post-rumen microbial supply of total AA in the new protein systems for ruminant feeding are derived from measures of the efficiency of microbial protein synthesis (expressed as $\mathrm{g}$ microbial $\mathrm{N}$ synthesized/kg organic matter fermented or digested in the rumen), assuming a constant proportion of AA in the microbial crude protein. Nevertheless, results of the present study show that the $\mathrm{AA}: \mathrm{N}$ ratio decreases as the rumen outflow rate increases (Fig. 2(b)). In addition, as the proportion of AA is lower in $\mathrm{LAB}$ than $\mathrm{SAB}$, the use of $\mathrm{LAB}$ as a reference sample produces an additional underestimation if the microbial supply to the intestine is determined as AA and not as total $\mathrm{N}$. This last point becomes more evident when purines are employed as microbial markers, as a consequence of the opposite behaviour observed for purine : $\mathrm{N}$ and total AA : N ratios in relation to the turnover rates.

In conclusion, the rumen outflow rate is the main factor that influences the $\mathrm{N}$ composition of rumen bacteria. An increment of this rate is associated with an increase of the concentration of purines in bacteria and a decrease of their true protein content. These relationships partially explain the differences in chemical composition between LAB and $\mathrm{SAB}$. When microbial protein is estimated using $\mathrm{LAB}$ as reference sample, the underestimation due to the differences for the marker: $\mathrm{N}$ ratio between $\mathrm{LAB}$ and $\mathrm{SAB}$ are greater when using purines instead of ${ }^{15} \mathrm{~N}$.

\section{Acknowledgements}

This work has been supported by the CICYT funded Project GAN 89-0126. Analyses of ${ }^{15} \mathrm{~N}$ isotope ratios were performed at the Servicio Interdepartamental de Investigación, Universidad Autónoma de Madrid, Spain. Analyses of purines were performed at the laboratories of the Departamento de Producción Animal y Ciencias de los Alimentos, Universidad de Zaragoza, Spain.

\section{References}

Association of Official Analytical Chemists (1984) Official Methods of Analysis, 14th ed. Arlington, VA: AOAC.

Balcells J, Guada JA, Peiró JM \& Parker DS (1992) Simultaneous determination of allantoin and oxypurines in biological fluids by high-performance liquid chromatography. Journal of Chromatography 575, 153-157.

Bates DB, Gillett JA, Barao SA \& Bergen WR (1985) The effect of specific grow rate and stage of growth on nucleic acid-protein values of pure cultures and mixed ruminal bacteria. Journal of Animal Science 61, 713-724.

Bauchart D, Legay-Carmier F, Doreau M \& Jouany JP (1986) Effects of the addition of non-protected fat in rations for milk cows over the concentration and chemical composition of rumen bacteria and protozoa. Reproduction Nutrition Développement 26, 309-310.

Beckers Y, Thewis A, Maudoux B \& Francois E (1995) Studies on the in situ nitrogen degradability corrected for bacterial contamination of concentrate feeds in steers. Journal of Animal Science 73, 220-227.

Benchaar C, Bayourthe C, Vernay M \& Moncoulon R (1995) Composition chimique des bactéries libres ou adhérentes au contenu du rumen et du duodénum chez la vache (Chemical 
composition of bacteria free or attached to rumen or duodenum content in cows). Annales de Zootechnie 44, Suppl., 139.

Bremer H \& Dennis PP (1987) Modulation of chemical composition and other parameters of the cell by growth rate. In Escherichia coli and Salmonella typhimurium: Cellular and Molecular Biology, vol. 2, chapter 96 [FC Neidhardt, JL Ingraham, KB Low, B Magasanik, M Schaechter and HE Umbarger, editors]. Washington, DC: American Society for Microbiology.

Cecava MJ, Merchen NR, Gay LC \& Berger LL (1990) Composition of ruminal bacteria harvested from steers as influenced by dietary energy level, feeding frequency, and isolation techniques. Journal of Dairy Science 73, 2480-2488.

Craig WH, Broderick GA \& Bradford RO (1987a) Quantitation of micro-organisms associated with the particulate phase of ruminal digesta. Journal of Nutrition 117, 56-62.

Craig WM, Brown DR, Broderick GA \& Ricker DB (1987b) Postprandial compositional changes of fluid- and particle-associated ruminal micro-organisms. Journal of Animal Science 65, 10421048.

Cummins CS (1989) Bacterial cell wall structure. In Practical Handbook of Microbiology, pp. 349-379 [MW O'Leary, editor]. Boca Raton, FL: CRC Press Inc.

Dhanoa MS, Siddons RC, France J \& Gale DL (1985) A multicompartmental model to describe marker excretion patterns in ruminant faeces. British Journal of Nutrition 53, 663-671.

Dixon RM, Nolan JV \& Milligan LP (1982) Studies of the large intestine of sheep. 2 - Kinetics of liquid and solid phase markers in the caecum and proximal colon. British Journal of Nutrition 47, 301-309.

Ellis WC \& Beever KC (1984) Methods for binding rare earth to specific feed particles. In Techniques in Particle Size Analysis of Feed and Digesta in Ruminants, pp. 154-165 [CPM Kennedy, editor]. Edmonton, Alberta: Canadian Society of Animal Science.

Ellis W, Matis JH \& Lascano C (1979) Quantitating ruminal turnover. Federation Proccedings 38, 2702-2706.

Ellis W, Wylie MJ \& Matis JH (1988) Dietary-digestive interactions determining the feeding value of forages and roughages. In Feed Science, pp. 177-299 [ER Ørskov, editor]. Amsterdam: Elsevier Science Publishers BV.

Firkins JL, Berger LL, Merchen NR, Fahey GC Jr \& Mulvaney RL (1987) Ruminal nitrogen metabolism in steers as affected by feed intake and dietary urea concentration. Journal of Dairy Science 70, 2302-2311.

Folch J, Lees M \& Sloane Stanley GH (1957) A simple method for the isolation and purification of total lipides from animal tissues. Journal of Biological Chemistry 226, 497-509.

Grovum WL \& Williams VJ (1973) Rate of passage of digesta in sheep. 4. Passage of marker through the alimentary tract and the biological relevance of rate-constants derived from the changes in concentration of marker in faeces. British Journal of Nutrition 30, 313-329.

Harfoot GG (1981) Lipid metabolism in the rumen. In Lipid Metabolism in Ruminant Animals, pp. 21-55 [WW Christie, editor]. Oxford: Pergamon Press.

Hespell RB \& Bryant MP (1979) Efficiency of rumen microbial growth: influence of some theoretical and experimental factors on Y ATP. Journal of Animal Science 49, 1640-1659.

Jones BR, Pääbo S \& Stein S (1981) Amino acid analysis and enzymatic sequence determination of peptides by an improved o-phthaldialdehyde precolumn labelling procedure. Journal of Liquid Chromatography 4, 565-586.

Komisarczuk S, Durand M, Beaumatin Ph \& Hannequart G (1987) Utilisation de l'azote 15 pour la mesure de la protéosynthése microbienne dans les phases solide et liquide d'un fermenteur semi-continu (Rusitec) (Use of ${ }^{15} \mathrm{~N}$ to measure the microbial protein synthesis in the solid and liquid phases of a semicontinuous fermenter (Rusitec)). Reproduction Nutrition Dévelopement 27, 261-262.

Latham MJ (1980) Adhesion of rumen bacteria to plant cell walls. In Microbial Adhesion to Surfaces, pp. 339-350 [RCW Berkeley, JM Lynch, J Melliney, RP Rutter and B Vincent, editors]. Chichester: Ellis Howard.

Legay-Carmier F \& Bauchart D (1989) Distribution of bacteria in the rumen contents of dairy cows given a diet supplemented with soyabean oil. British Journal of Nutrition 61, 725-740.

Martin C, Williams AG \& Michalet-Doreau B (1994) Isolation and characteristics of the protozoal and bacterial fractions from bovine ruminal contents. Journal of Animal Science 72, 29622968.

Martin C, Bernard L \& Michalet-Doreau B (1996) Influence of sampling time and diet on amino acid composition of protozoal and bacterial fractions from bovine ruminal contents. Journal of Animal Science 74, 1157-1163.

Merry RJ \& McAllan AB (1983) A comparison of the chemical composition of mixed bacteria harvested from the liquid and solids fractions of rumen digesta. British Journal of Nutrition 50, 701-709.

Olubobokun JA \& Craig WM (1990) Quantity and characteristics of micro-organisms associated with ruminal fluid or particles. Journal of Animal Science 68, 3360-3370.

Olubobokun JA, Craig WM \& Pond KR (1990) Effects of mastication and microbial contamination on ruminal in situ forage disappearance. Journal of Animal Science 68, 3371-3381.

Pirt SJ (1975) Principles of Microbe and Cell Cultivation. Oxford: Blackwell Science Publishers.

Poncet C (1991) The outflow of particles from the reticulo-rumen. In Rumen Microbial Metabolism and Ruminant Digestion, pp. 297-322 [JP Jouany, editor]. San Diego, CA: Academic Press.

Robertson JB \& Van Soest PJ (1981) The detergent system of analysis and its application to human foods. In The Analysis of Dietary Fiber in Food, pp. 123-158 [WPT James and O Theander, editors]. New York, NY: Marcel Dekker.

Schaechter M, Maaløe O \& Kjeldgaard NO (1958) Dependency on medium and temperature of cell size and chemical composition during balanced growth of Salmonella typhimurium. Journal of General Microbiology 19, 592-606.

Uden P, Colucci PE \& Van Soest PJ (1980) Investigation of chromium, cerium and cobalt as markers in digesta. Rate of passage studies. Journal of the Science of Food and Agriculture 31, 625-632.

Waghorn GC \& Reid CSW (1977) Rumen motility in sheep and cattle as effected by feeds and feeding. Proceedings of the New Zealand Society of Animal Production 37, 176.

Williams AG \& Strachan NH (1984) Polysaccharide degrading enzymes in microbial population from the liquid and solid fractions of bovine rumen digesta. Canadian Journal of Animal Science 64, Suppl., 58-59. 